\title{
ドロマイトを用いたアルミン酸ソーダ 溶液の脱ケイ酸処理について*
}

\author{
正会員伊藤尚 ${ }^{* *}$ \\ 正会員柳 ケ瀬勉** \\ 正会員宮本乙次 郎 ${ }^{* * *}$
}

Removal of Silica in Sodium Aluminate Solution by Dolomite

Hisashi ITO, Tsutomu YANAGASE and Otojiro MIYAMOTO

\begin{abstract}
The removal of silica dissolved in sodium aluminate solution is one of the serious problems in production of highly purified alumina. The solution used here was prepared by leaching the laterite ore roasted with $\mathrm{Na}_{2} \mathrm{CO}_{3}$. Among various addition agents so far used for removal of silica, it was found that the dolomite gave the best results and about $99 \%$ of silica was removed as a result of heat treatment of the solution in autoclave at $170^{\circ} \mathrm{C}$, thus resulted in less than 0.03 as a value of $\mathrm{SiO}_{2} \times 100 / \mathrm{Al}_{2} \mathrm{O}_{3}$ in the solution. The products formed by addition of dolomite powder coniained calcium silicate hydrate, calcium aluminum hydroxide and basic aluminum silicate besides excess dolomile.
\end{abstract}

\section{1. 緒言}

金属アルミニウムの製造原料であるアルミナは高純度 のボーキサイトを原料として，苛性ソーダを用いて，ア ルミナをアルミン酸ソーダ $\left(\mathrm{NaAlO}_{2}\right)$ として抽出し，不 純物の鉄やケイ酸などは不溶性の赤泥として分離除去し た後に，水酸化アルミニウムを析出させ，分離，焙焼し てアルミナとするいわゆるバイヤー法，およびその改良 法によつて広く製造されているが1),2)，金属アルミニウ ムの需要急増にもかかわらず，高品位のボーキサイトが 世界的に不足しつつある現在，ボーキサイト以外の原料 から経済的なアルミナ製造が重要視されてきた。しか し，このような低品位アルミナ鉱を原料とした場合の問 題点の一つに, 抽出液のケ, イ酸濃度の高いことがあげら れ，この液の脱ケイ酸は，アルミナを析出した後では非 常にむずかしいのでアルミナ析出前にケイ酸を除去し清 浄なアルミン酸ソーダ溶液とすることが必要である。

本実験では，ラテライトを原料とし，これにソーダ死 を添加し高温焙焼したものを水で抽出して得られた，い わゆるソーダ焙燒抽出液を用いて種々な脱ケイ剤, 脱ケ イ条件について比較検討を行なつた。用いたアルミン酸 ソーダ溶液は, 溶液中の $\mathrm{Al}_{2} \mathrm{O}_{3}$ の溶存量が $30 \sim 60 \mathrm{~g} / \mathrm{l}$

\footnotetext{
* 昭和 42 年 8 月 18 日受理 昭和 42 年 4 月, 日本鉣丵会春季大会汒 て発表

** 工博 九州大学教授 工学部冶金学科

**** 九州大学助手 工学部治金学科
}

とかなり低濃度で, しかもケイ酸量は $0.5 \sim 2.0 \mathrm{~g} / l$ と高 くこの溶液をオートクレーブを用いて高温加圧方式で各 種単味の添加剤および組合せ添加剂を用いた脱ケイ酸処 理実験を行ない，さらに添加量などの影響について検討 した。その中で現在まで用いられたことのなかつたドロ マイト $\left[\mathrm{Ca}, \mathrm{Mg}\left(\mathrm{CO}_{3}\right)_{2}\right]$ の生鉱および燒鉱を脱ケイ剤と して添加した場合，良好な結果が得られる事を見出した のでその添加量, 粒度の影響およびその他の添加物を組 合せての脱ケイ酸処理実験を行ない, あわせて脱ケイ酸 機構についても検討を加えた結果を報告する。

\section{2. 装置むよび添加㶡}

\section{$2 \cdot 1$ 装 置}

脱ケイ酸処理には, 次のオートクレーブを用い, ケイ 酸の定量には島津分光光度計を使用した。

(a) 坂下式電磁攪挥オートクレーブSE-50型 釜材質……テンレス製，容量……500m l，常用圧 力…3...300ATM，常用温度……300

（b）島津 $Q R$ 型分光光度計（1 cm セルを使用）

\section{$2 \cdot 2$ 添加剂}

脱ケイ酸処理には次のような添加剤を使用した。

(a) $\mathrm{Al}(\mathrm{OH})_{3}, \mathrm{Ca}(\mathrm{OH})_{2}$ は実験室で調製し, 湿つ

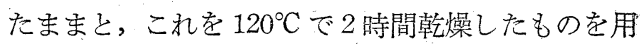
いた。

(b) Dolomite はすべて -200 mesh に粉砕した生鉱 
とこれを $1,000^{\circ} \mathrm{C}$ で 2 時間以上カ焼したものを用い た。

(c) 鉱滓，電気炉・転炉・平炉滓などをー200mesh に粉砕して用いた。

(d) カオリン $\mathrm{Al}_{4} \mathrm{Si}_{4} \mathrm{O}_{11}(\mathrm{OH})_{8} ・ 4 \mathrm{H}_{2} \mathrm{O}$ の生鉱物を -200meshに粉砕して用いた。

その他の添加剤はすべて試薬一級品を用いた。

\section{3. 抽出液の経時变化}

抽出液中に多量のケイ酸が存在すると, アルミナやソ 一ダなどと結合してゲル状の沈殿物が生成し，日時の経 過にしたがい抽出液の組成を刻々变化させる。その沈殿 物の形態は常温ではZeolite $\left[\left(\mathrm{Na} \cdot \mathrm{Al} \cdot \mathrm{SiO}_{4}\right)_{12} \cdot m \mathrm{H}_{2} \mathrm{O}\right]$ で あるが,これは変化しやすく, 長時間抽出液中に放置する と次第に Basic Sodalite $\left(\mathrm{Na}_{2} \mathrm{O} \cdot \mathrm{Al}_{2} \mathrm{O}_{3} \cdot 2 \mathrm{SiO}_{2} \cdot n \mathrm{H}_{2} \mathrm{O}\right)$ に変化する。また文献によれば温度の影響によつてその 変化が促進されると防れている ${ }^{3), 4}$ 。このような生 成物の形態を知るため, 抽出液近似の合成液を調製し, これに水ガラス $\left(\mathrm{Na}_{2} \mathrm{SiO}_{3}\right)$ 水溶液をケイ酸として約 $5 \mathrm{~g} / l$ になるように加えた混合液を分取し，室温で 1日1〜2回 かきまぜながら数日間放置後, 得られた生成物, ならび に前述の混合液をオートクレーブに移し $130^{\circ} \mathrm{C}, 155^{\circ} \mathrm{C}$, $170^{\circ} \mathrm{C}$ の 各温度で 2 時間高温加圧処理して得られた生成 物をX線回折によつてその構造を検討した結果，常温お よび $130^{\circ} \mathrm{C}$ 処理生成物はZeoliteで, $155^{\circ} \mathrm{C}$ 処理生成物では ZeoliteとBasic Sodalite が混在し， $170^{\circ} \mathrm{C}$ 処理でほとん ど Basic Sodalite として生成することを認めた。次に アルカリ濃度の異なつた抽出液を毎月組成分析を行ない 組成の変化を検討した結果を第 1 表に示す。

これによつてわかるようにケイ酸は, 焙燒の際に添加 するソーダ量の少ない No. 1 2 抽出液では， 5 力月間

第 1 表 抽出液組成の経時変化

\begin{tabular}{|c|c|c|c|c|c|c|c|c|}
\hline \multicolumn{2}{|c|}{ 抽出原液 } & \multirow{2}{*}{$\begin{array}{l}\text { 経 } \\
\text { 過 } \\
\text { 等 }\end{array}$} & \multicolumn{3}{|c|}{ 液 } & 組 & 成 & \\
\hline No. & 種 別 & & $\begin{array}{c}\mathrm{SiO}_{2} \\
(\mathrm{mg} / \mathrm{l})\end{array}$ & $\begin{array}{c}\mathrm{Al}_{2} \mathrm{O}_{3} \\
(\mathrm{~g} / l)\end{array}$ & $\begin{array}{l}\mathrm{CrO}_{3} \\
(\mathrm{~g} / l)\end{array}$ & $\begin{array}{c}\mathrm{NaOH} \\
(\mathrm{g} / \mathrm{l})\end{array}$ & $\left|\begin{array}{c}\mathrm{Na}_{2} \mathrm{CO}_{3} \\
(\mathrm{~g} / l)\end{array}\right|$ & $\begin{array}{c}\mathrm{T} . \mathrm{Na}_{2} \mathrm{O} \\
(\mathrm{g} / l)\end{array}$ \\
\hline 1 & $\begin{array}{l}\mathrm{Na}_{2} \mathrm{CO}_{3} \\
150 \mathrm{~kg} / \mathrm{t}\end{array}$ & $\begin{array}{l}0 \\
1 \\
2 \\
3 \\
4\end{array}$ & $\begin{array}{l}493 \\
430 \\
300 \\
240 \\
120\end{array}$ & $\begin{array}{l}26.35 \\
25.15 \\
21.50 \\
21.35 \\
18.45\end{array}$ & $\begin{array}{l}9.84 \\
9.86 \\
9.86 \\
9.92 \\
9.91\end{array}$ & $\begin{array}{l}16.43 \\
14.16 \\
13.92 \\
13.09 \\
13.87\end{array}$ & \begin{tabular}{l|}
18.82 \\
24.16 \\
25.52 \\
25.69 \\
23.43
\end{tabular} & $\begin{array}{l}23.51 \\
25.11 \\
25.72 \\
25.17 \\
24.45\end{array}$ \\
\hline 2 & $\begin{array}{r}\mathrm{Na}_{2} \mathrm{CO}_{3} \\
248 \mathrm{~kg} / \mathrm{t}\end{array}$ & $\begin{array}{l}0 \\
2 \\
3 \\
4 \\
5\end{array}$ & $\begin{array}{l}980 \\
690 \\
603 \\
430 \\
270\end{array}$ & $\begin{array}{l}30.80 \\
30.60 \\
29.30 \\
29.65 \\
29.30\end{array}$ & $\begin{array}{l}21.20 \\
21.17 \\
21.17 \\
21.27 \\
21.38\end{array}$ & $\begin{array}{r}22.80 \\
28.20 \\
25.10 \\
26.56 \\
26.88\end{array}$ & $\begin{array}{l}48.10 \\
35.90 \\
41.90 \\
39.47 \\
36.87\end{array}$ & $\begin{array}{l}45.90 \\
42.90 \\
44.80 \\
43.69 \\
42.69\end{array}$ \\
\hline 3 & $\begin{array}{l}\mathrm{Na}_{2} \mathrm{CO}_{3} \\
300 \mathrm{~kg} / \mathrm{t}\end{array}$ & $\begin{array}{l}0 \\
1\end{array}$ & $\begin{array}{l}1,665 \\
1,525\end{array}$ & $49.1 \overline{5}$ & \begin{tabular}{|l|}
15.05 \\
14.97
\end{tabular} & $\begin{array}{l}57.49 \\
58.97\end{array}$ & $\begin{array}{l}47.49 \\
39.85\end{array}$ & $\begin{array}{l}71.17 \\
69.02\end{array}$ \\
\hline 4 & $\begin{array}{r}\mathrm{Na}_{2} \mathrm{CO}_{3} \\
400 \mathrm{~kg} / \mathrm{t}\end{array}$ & $\begin{array}{l}0 \\
1 \\
2\end{array}$ & $\begin{array}{l}1,525 \\
1,260 \\
1,300\end{array}$ & $\begin{array}{l}57.20 \\
56.75 \\
55.00\end{array}$ & $\begin{array}{l}17.86 \\
17.80 \\
17.60\end{array}$ & $\begin{array}{l}83.67 \\
78.76 \\
83.49\end{array}$ & $\begin{array}{l}44.86 \\
51.66 \\
41.51\end{array}$ & $\begin{array}{l}91.08 \\
91.26 \\
88.98\end{array}$ \\
\hline 5 & $\begin{array}{l}\mathrm{Na}_{2} \mathrm{CO}_{3} \\
500 \mathrm{~kg} / \mathrm{t}\end{array}$ & $\begin{array}{l}0 \\
1 \\
2\end{array}$ & $\begin{array}{l}1,950 \\
1,815 \\
1,830\end{array}$ & \begin{tabular}{|l|}
54.75 \\
54.75 \\
54.25
\end{tabular} & $\begin{array}{l}15.04 \\
14.87 \\
14.89\end{array}$ & $\begin{array}{l}94.69 \\
94.33 \\
96.73\end{array}$ & $\begin{array}{l}52.29 \\
45.48 \\
42.72\end{array}$ & $\begin{array}{r}103.98 \\
99.71 \\
99.99\end{array}$ \\
\hline
\end{tabular}

$124\langle 48\rangle$
に70\%以上減少し，ソーダ量の多い抽出液では経過日時 が浅くその挙動の変化については考察し難いが，1 カ月 後において 6 17\% 減少している。アルミナも大体ケイ 酸の挙動と同じことがいえるが, 特にNo. 1 抽出液のご とくソーダ灰配合量の少ない抽出液において約 $20 \%$ 減 少率を示している。またソーダも同様に日時の経過にし たがい減少している。このことから次式

$$
\begin{aligned}
& 2\left(\mathrm{Na}_{2} \mathrm{O} \cdot \mathrm{SiO}_{2}\right)+2 \mathrm{NaAlO}_{2}+4 \mathrm{H}_{2} \mathrm{O} \\
& =\mathrm{Na}_{2} \mathrm{O} \cdot \mathrm{Al}_{2} \mathrm{O}_{3} \cdot 2 \mathrm{SiO}_{2} \cdot 2 \mathrm{H}_{2} \mathrm{O}+4 \mathrm{NaOH}
\end{aligned}
$$

の上うに不溶解性のナトリウム・アルミニウム・シリケ 一トを作り減少したものと考えられる。一般に抽出液中 のアルカリ濃度の弱いほど $\mathrm{SiO}_{2}, \mathrm{Al}_{2} \mathrm{O}_{3}, \mathrm{Na}_{2} \mathrm{O}$ の減少 は増大し, その経持変化が䫑著であることがいえる。

\section{4. 脱ケイ酸処理}

前述のように抽出液おにケイ酸が存在すると高価なソ 一ダやアルミナが脱ケイ酸生成物として失なわれる。特 に重要な問題は不十分な脱ケイによるアルミナ品位の低 下である。

そこで抽出液けのケイ酸濃度を極力小さくするため， オートクレーブを用いた高温加圧方式を採用し5，各種 単味衫よび組合せ脱ケイ剂を用いた脱ケイ酸処理実験を 行ない,さらにその添加量の影響についても検討した。

\section{$4 \cdot 1$ 实駼方泣}

一定量の試料溶液と脱ケイ猟をオートクレーブに入れ 攪汼しながら $170^{\circ} \mathrm{C}$ で 2 時間高温加王処理を行ない， 1 夜放置後, ろ過洗浄した精製液の組成分析字行ない, 脱 ケイ剤の差異による脱ケイ率およびその組成の変化を検 討した。

\section{$4 \cdot 2$ 実験結果および考察}

（1）各種脱ケイ斉による脱ケイ酸 抽出液 $50 \mathrm{~m} l$ を分取し, $\mathrm{MgSO}_{4}, \mathrm{FeSO}_{4}, \mathrm{FeCO}_{3}, \mathrm{CaCl}_{2}, \mathrm{CaSO}_{4}$, $\mathrm{CaCO}_{3}, \mathrm{Ca}(\mathrm{OH})_{2}$, カオリン鉱物および 鉱㳯などを各 々 $10 \mathrm{~g} /$ / の割合で添加し，前述の実験方法にもとづき脱 ケイ酸処理を行なつた後の精製液の組成分析を行ない組 成の変化を検討した結果を第 2 表に示す。

これによると脱ケイ剤を添加しない場合の脱尔率は $59 \%$ と低いが，種々の脱ケイ剂を添加すると70\%以上に 上昇する。とくに Ca系の添加物が最も優秀な脱ケイ率 を示し，精製液中における $\mathrm{SiO}_{2} / \mathrm{Al}_{2} \mathrm{O}_{3} \times 100$ の值も0.05 〜0.09程度に低下し良好な結果を得た。しかるに Ca 系 の添加物を用いた場合, 溶液中の $\mathrm{Al}^{+++}$の減少がはな ぼなしく $20 \%$ 以上損失することがわかつた。

その他 $\mathrm{MgSO}_{4}, \mathrm{Fe}$ 系, カオリンおよび各種鉱滓など の添加物も70～95\%と脱ケイ剤としての効果は現われて いるが，いずれも $\mathrm{SiO}_{2} / \mathrm{Al}_{2} \mathrm{O}_{3} \times 100$ の值が 0.1 以上で期 待された結果は得られなかつた。 
第2 表各種添加物による脱ケイ率の変化

A 抽出液採取量 $50 \mathrm{~m} l, B$ 抽出液採取量 $500 \mathrm{~m} l$, 処理温度拉よび処理時間 $170^{\circ} \mathrm{C} 2 \mathrm{~h}$, 放置時間 1 日

\begin{tabular}{c|c|c|r|r|r|r|r}
\hline \hline \multirow{2}{*}{ No. } & \multicolumn{3}{|c}{ 原 } & \multicolumn{2}{|c|}{ 液 } & \multicolumn{3}{c}{ 組 } \\
\cline { 2 - 8 } & $\mathrm{SiO}_{2}(\mathrm{~g} / l)$ & $\mathrm{Al}_{2} \mathrm{O}_{3}(\mathrm{~g} / l)$ & $\mathrm{CrO}_{3}(\mathrm{~g} / l)$ & $\mathrm{NaOH}(\mathrm{g} / l)$ & $\begin{array}{c}\mathrm{Na}_{2} \mathrm{CO}_{3} \\
(\mathrm{~g} / l)\end{array}$ & $\begin{array}{c}\mathrm{T} . \mathrm{Na}_{2} \mathrm{O} \\
(\mathrm{g} / l)\end{array}$ & $\frac{\mathrm{SiO}_{2} \times 100}{\mathrm{Al}_{2} \mathrm{O}_{3}}$ \\
\hline $\mathrm{A}$ & 0.900 & 30.30 & 8.64 & 33.52 & 28.98 & 42.93 & 2.970 \\
$\mathrm{~B}$ & 0.603 & 29.30 & 21.17 & 25.10 & 41.90 & 44.80 & 2.058 \\
\hline
\end{tabular}

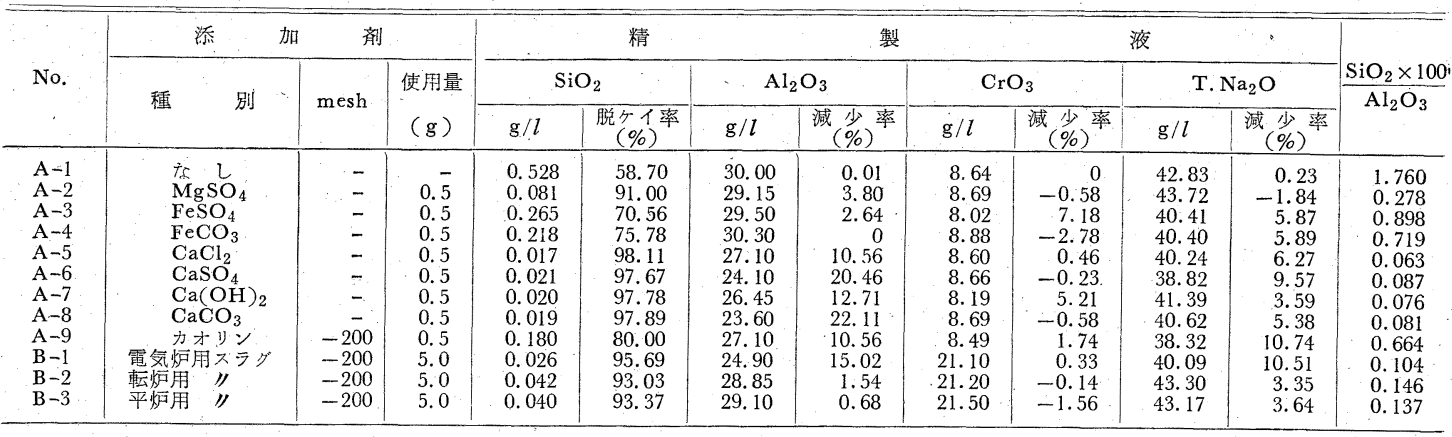

第 3 表 $\mathrm{Al}, \mathrm{Ca}$ 各水酸化物添加量の影響

原液採取量 $50 \mathrm{~m} l$ ，処理温度就よび処理時間 $170^{\circ} \mathrm{C} 2 \mathrm{~h}$, 放置時間 1 日

\begin{tabular}{c|c|c|c|c|c|c}
\hline \multicolumn{2}{c}{ 原 } & \multicolumn{2}{c}{ 液 } & \multicolumn{2}{c}{ 成 } \\
\hline $\mathrm{SiO}_{2}(\mathrm{~g} / l)$ & $\mathrm{Al}_{2} \mathrm{O}_{3}(\mathrm{~g} / l)$ & $\mathrm{CrO}_{3}(\mathrm{~g} / l)$ & $\mathrm{NaOH}(\mathrm{g} / l)$ & $\mathrm{Na}_{2} \mathrm{CO}_{3}(\mathrm{~g} / l)$ & $\mathrm{T} . \mathrm{Na}_{2} \mathrm{O}(\mathrm{g} / l)$ & $\frac{\mathrm{SiO}_{2} \times 100}{\mathrm{Al}_{2} \mathrm{O}_{3}}$ \\
\hline 0.895 & 30.20 & 8.80 & 33.53 & 28.89 & 42.94 & 2.964 \\
\hline
\end{tabular}

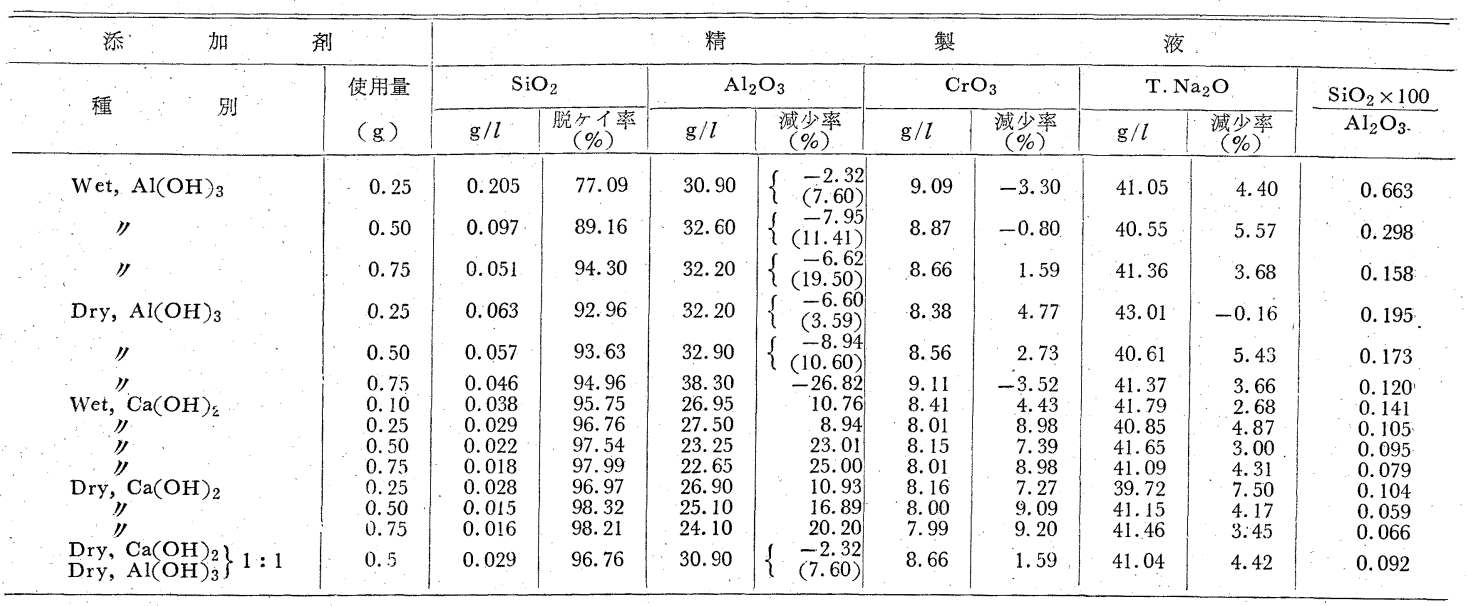

次に実験室で調製した $\mathrm{Al}(\mathrm{OH})_{3}$ おおよび $\mathrm{Ca}(\mathrm{OH})_{2}$ を添加剤としてその添加量を変えて脱ケイ酸処理した結 果安第 3 表に示す。

この結果を脱ケイ率の良い順位からみると乾燥 $\mathrm{Ca}(\mathrm{O}$ $\mathrm{H})_{2}$, 湿 $\mathrm{Ca}(\mathrm{OH})_{2}$, 乾燥 $\mathrm{Ca}(\mathrm{OH})_{2}$ と乾燥 $\mathrm{Al}(\mathrm{OH})_{3}$ を $1: 1$ の割合で混合したもの, 乾燥 $\mathrm{Al}(\mathrm{OH})_{3}$, 湿 $\mathrm{Al}(\mathrm{OH})_{3}$ の順序となり，両添加剤とも乾燥物を用いた方が良好で あつた。特に乾燥 $\mathrm{Ca}(\mathrm{OH})_{2}$ では $\mathrm{SiO}_{2} / \mathrm{Al}_{2} \mathrm{O}_{3} \times 100$ の 值が0.06まで低下し, 目標の0.03には達していないが脱 ケイ率も $98 \%$ とまずよい結果を示した。また添加郕の増 加にしたがい脱ケイ率は上昇するが， $\mathrm{Al}_{2} \mathrm{O}_{3}$ が前述同様 多量に減少し最高 $25 \%$ の損失率を示している。
（2）ドロマイトによる脱ヶイ酸，以上の結果から とくにCa系添加版が良好な結果を示し，Mg系もかなら ずしも不良とは考光られないことから，これらと近似の 組成をもつドロマイトを添加剤として用い, その添加量, 抽出液処理量および添加剤の組合せなどの影響について 検討した結果を第 4 表に一括して示す。

No. A 抽出原液 $50 \mathrm{~m} l$ にドロマイト生鉱，焼鉱を $10 \mathrm{~g}$ /にの割合で添加し脱ケイ酸处理を行なつた場合の結果 で，いずれを用いても脱ケイ率は良好で $\mathrm{SiO}_{2} / \mathrm{Al}_{2} \mathrm{O}_{3}$ × 100の值も0.04 0.06と目標值に近い結果を示している。

No. B は抽出原液処理量を $500 \mathrm{~m} l$ と増量してドロマイ 卜, 生鉱の添加量を $3 \sim 10 \mathrm{~g} /$ /の閒で変え, 脱ケイ酸処理 
ドロマイトを用いたアルミン酸ソーダ溶液の脱ケイ酸処理について

第4表 ドロマイトによる脱ケイ率およびミルスケール添加の影響

$\mathrm{A}$ 原液採取量 $50 \mathrm{~m} l, \mathrm{~B}$ s よび C 原液採取量 $500 \mathrm{~m} l$, 処理温度および処理時間 $170^{\circ} \mathrm{C} 2 \mathrm{~h}$, 放置時間 1 日

\begin{tabular}{c|c|c|c|c|c|c|c|}
\hline \hline \multirow{2}{*}{ No. } & \multicolumn{3}{|c|}{ 原 } & \multicolumn{2}{|c|}{ 液 } & \multicolumn{2}{|c|}{ 組 } \\
\cline { 2 - 8 } & $\mathrm{SiO}_{2}(\mathrm{~g} / l)$ & $\mathrm{Al}_{2} \mathrm{O}_{3}(\mathrm{~g} / l)$ & $\mathrm{CrO}_{3}(\mathrm{~g} / l)$ & $\mathrm{NaOH}(\mathrm{g} / l)$ & $\begin{array}{c}\mathrm{Na}_{2} \mathrm{CO}_{3} \\
(\mathrm{~g} / l)\end{array}$ & $\begin{array}{c}\mathrm{T} . \mathrm{Na}_{2} \mathrm{O} \\
(\mathrm{g} / l)\end{array}$ & $\frac{\mathrm{SiO}_{2} \times 100}{\mathrm{Al}_{2} \mathrm{O}_{3}}$ \\
\hline $\mathrm{A}$ & 0.900 & 30.30 & 8.64 & 33.52 & 28.98 & 42.93 & 2.970 \\
$\mathrm{~B}$ & 0.980 & 30.80 & 21.20 & 22.80 & 48.10 & $45 . \mathrm{c} 0$ & 3.182 \\
$\mathrm{C}$ & 0.478 & 47.85 & 15.38 & 62.82 & 33.47 & 68.27 & 0.999 \\
\hline
\end{tabular}

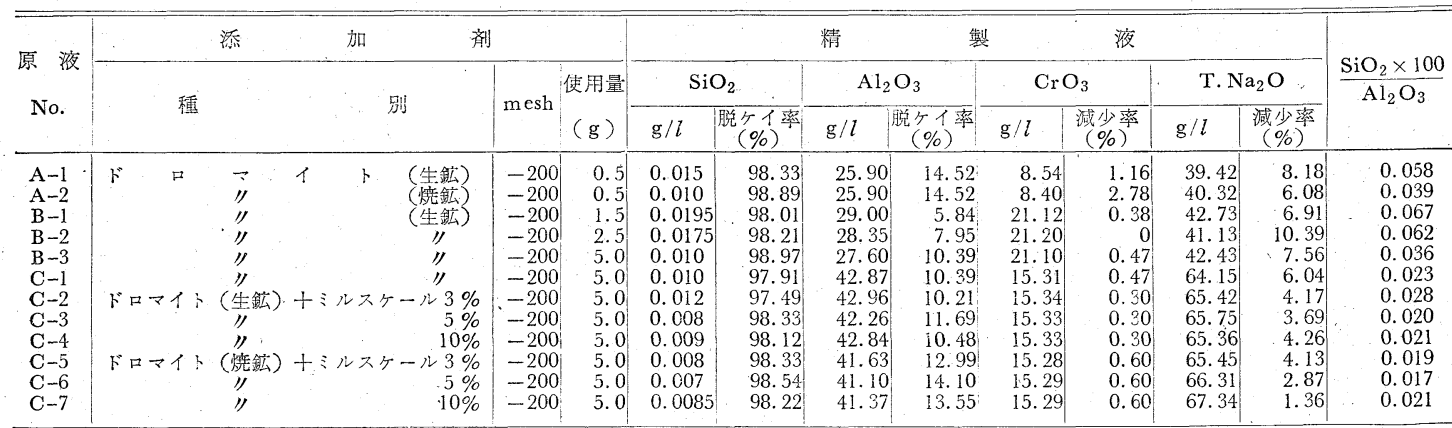

第 5 表 各種ドロマイト粒度の影響

原液採取量 $500 \mathrm{~m} l$, 処理温度预よび 処理時間 $170^{\circ} \mathrm{C} 2 \mathrm{~h}$, 放罡時間 1 日

\begin{tabular}{|c|c|c|c|c|c|c|c|}
\hline \multirow{2}{*}{$\begin{array}{l}\text { 原 液 } \\
\text { No. }\end{array}$} & \multicolumn{3}{|c|}{ 原 } & 夜 & 组 & \multicolumn{2}{|c|}{ 成 } \\
\hline & $\mathrm{SiO}_{2}(\mathrm{~g} / l)$ & $\mathrm{Al}_{2} \mathrm{O}_{3}(\mathrm{~g} / \mathrm{l})$ & $\mathrm{CrO}_{3}(\mathrm{~g} / \mathrm{l})$ & $\mathrm{NaOH}(\mathrm{g} / \mathrm{l})$ & $\begin{array}{c}\mathrm{Na}_{2} \mathrm{CO}_{3} \\
(\mathrm{~g} / l)\end{array}$ & $\underset{(\mathrm{g} / l)}{\mathrm{T} / \mathrm{Na}}$ & $\frac{\mathrm{SiO}_{2} \times 100}{\mathrm{Al}_{2} \mathrm{O}_{3}}$ \\
\hline $\begin{array}{l}\mathrm{A} \\
\mathrm{B} \\
\mathrm{C}\end{array}$ & $\begin{array}{l}0.980 \\
0.690 \\
0.603\end{array}$ & $\begin{array}{l}30.80 \\
30.60 \\
29.30\end{array}$ & $\begin{array}{l}21.20 \\
21.17 \\
21.17\end{array}$ & $\begin{array}{l}22.80 \\
28.20 \\
25.10\end{array}$ & $\begin{array}{l}48.10 \\
35.90 \\
41.90\end{array}$ & $\begin{array}{l}45.90 \\
42.90 \\
44.80\end{array}$ & $\begin{array}{l}3.182 \\
2.255 \\
2.058\end{array}$ \\
\hline D & 0.430 & 29.65 & 21.27 & 26.56 & 39.47 & 43.69 & 1.450 \\
\hline
\end{tabular}

\begin{tabular}{|c|c|c|c|c|c|c|c|c|c|c|c|c|c|}
\hline \multirow{3}{*}{$\begin{array}{c}\text { 原 液 } \\
\text { No. }\end{array}$} & \multicolumn{2}{|l|}{ 添 } & \multicolumn{2}{|l|}{ 剤 } & \multicolumn{4}{|c|}{ 精 } & \multicolumn{4}{|c|}{ 液 } & \multirow{3}{*}{$\frac{\mathrm{SiO}_{2} \times 100}{\mathrm{Al}_{2} \mathrm{O}_{3}}$} \\
\hline & \multirow{2}{*}{ 種 } & \multirow{2}{*}{ 別 } & \multirow{2}{*}{ mash. } & \multirow{2}{*}{$\begin{array}{l}\text { 使用量 } \\
(\mathrm{g} / l)\end{array}$} & \multicolumn{2}{|c|}{$\mathrm{SiO}_{2}$} & \multicolumn{2}{|c|}{$\mathrm{Al}_{2} \mathrm{O}_{3}$} & \multicolumn{2}{|c|}{$\mathrm{CrO}_{3}$} & \multicolumn{2}{|c|}{ T. $\mathrm{Na}_{2} \mathrm{O}$} & \\
\hline & & & & & $\mathrm{mg} / l$ & $\begin{array}{l}\text { 脱攵イ率 } \\
(\%)\end{array}$ & $\mathrm{g} / l$ & $\begin{array}{l}\text { 減少率 } \\
\end{array}$ & $\mathrm{g} / l$ & $\begin{array}{l}\text { 減少率 } \\
\end{array}$ & $\mathrm{g} / l$ & $\begin{array}{c}\text { 減少率 } \\
(\%)\end{array}$ & \\
\hline D & レンガ用ドロマイト & （生鉣） & $|-80 \sim+100|$ & 10.0 & 31.5 & 92.67 & 29.05 & 2.02 & 21.46 & 0.89 & 42.39 & 2.98 & 0.108 \\
\hline $\mathrm{D}$ & I) & 11 & $-150 \sim+200$ & & & 91.86 & & & & & & & \\
\hline & 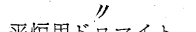 & ") & -200 & 10.0 & 27. & 97. & 28. & 6.66 & 21.19 & -0 & & 10. & \\
\hline $\mathrm{D}$ & 平炉用ドロマイト & （生鉣） & $|-80 \sim+100|$ & 10.0 & 44. & 89. & 32. & -7.92 & 21.29 & -0.0 & & & \\
\hline D & II & II & $-150 \sim+200 \mid$ & & 21. & & 28. & 2.7 & 21. & & & -2 & \\
\hline A & 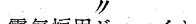 & 11 & -200 & & 19.0 & 98. & 29.0 & 5.8 & 21. & -0.14 & 42. & & \\
\hline D & 電気炉用ドロマイト & （生鉱） & $-80 \sim+100$ & 10.0 & 48. & 88. & & 1.8 ( & 21. & -0.19 & & -0 . & 0.165 \\
\hline $\mathrm{D}$ & "I & I) & $-150 \sim+200$ & 10.0 & & 90. & 29. & & 21. & $-0: \varepsilon$ & 44. & -1 & 0.1 \\
\hline A & 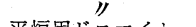 & 17 & -200 & 10. & 19. & & 28. & 6.17 & 21. & -0.0 & & 11. & 0.9 \\
\hline $\mathrm{B}$ & 平炉用ドロマイト & （䇌鉱） & $-80 \sim+100$ & 10. & 16. & & & & & -0.4 & & & \\
\hline $\mathrm{D}$ & I & & $|-100 \sim+150|$ & 10 & & 96. & 27. & 8. & 21. & -0.2 & & & \\
\hline D & " & "I & $|-150 \sim+200|$ & 10 & 13. & & & 10. & 21 & 0. & & & \\
\hline $\mathrm{C}$ & 䉓気炉用ドロマイト & （烧鉱） & $|-80 \sim+100|$ & 10 & 21. & & 28. & & & -1.0 & & & \\
\hline D & & & $\mid-100 \sim+150$ & 10 & 13. & & & & & -0 & & & \\
\hline D & "1 & ") & $|-150 \sim+200|$ & & & & & 7.7 & & 0. & & & \\
\hline $\mathrm{D}$ & "I & "I & -200 & 10.0 & 12.0 & 97.21 & 26.05 & 12.14 & 21.24 & 0.15 & 41.74 & 4.46 & 0.046 \\
\hline
\end{tabular}

実験を行なつた結果, 添加量の増加にしたがい精製液中 のケイ酸量は減少し， $10 \mathrm{~g} / l$ の添加量で抽出液の処理量 に関係なく約 $99 \%$ の脱ケイ率を示し $\mathrm{SiO}_{2} / \mathrm{Al}_{2} \mathrm{O}_{3} \times 100$ の 值も0.04と目標值の0.03と遜色ない結果が得られた。

次に各種の添加剤を組合せ，オートクレーブを用いて 前述のように脱々イ酸処理実験を行なつたが，ドロマイ ト単味に匹敵する添加物は見あたらなかつた。しかるに ドロマイト生鉱にミルスケール $(-200 \mathrm{mesh}) を 3 〜 10 \%$ 添加混合したものと，これらを $1,000^{\circ} \mathrm{C}$ で 2 時間力焼し たものとを添加剤として用いた結果, No. C $-2 \sim \mathrm{C}-7$ に 示すようにミルスケールの添加量にはあまり関係なく, いずれも $\mathrm{SiO}_{2} / \mathrm{Al}_{2} \mathrm{O}_{3} \times 100$ の值は目標值の 0.03 以下で
ドロマイト単味の場合より低值を示し, $\mathrm{Al}_{2} \mathrm{O}_{3}$ の損失率 も10.21 14.10\%と最良の結果が得られた。この原因に ついては現在検討中である。

（3）ドロマイト粒度の影響胡マイトが良好な 脱ケイ剂であることを見出したので，各種ドロマイトを -80meshよりー200mesh に粉砕し, 粒度別による脱ケ イ率を検討した結果を第 5 表に示す。これによると生鉱 ではいずれも粉砕度がかなり影響し，-200mesh以上を 必要とし，燒鉱では一部暴なつた結果がでているが大体 約ー100meshの粉砕度で一定した脱ケイ率を示してい る。また各種ドロマイトのー200mesh粉砕の生鉣を利用 した場合，いずれも脱ケイ率にはあまり大差はないが,ケ 
イ酸含有量の少ない程, 脱ケイ率が幾分上昇しているこ とから,比較的純度の高いドロマイトの使用が望ましい。

（4）ソータ配合量の脱ヶイ率におよぼす影響 各 種アルカリ濃度の異なつた抽出液にドロマイト生釷およ び焼鉱 (-200mesh) を $10 \mathrm{~g} /$ / 添加して脱ケイ酸処理学行 ない, 精製液の脱ケイ率, 残留ケイ酸および $\mathrm{SiO}_{2} / \mathrm{Al}_{2}$ $\mathrm{O}_{3} \times 100$ の值とソーダ配合量との関係を第 1 図に示す。 これによると脱ケイ率はいずれの添加剤に扔いてもソー ダ灰配合量にあまり関係はないが，残留ケイ酸および $\mathrm{SiO}_{2} / \mathrm{Al}_{2} \mathrm{O}_{3} \times 100$ の值はソーダ乍配合量の増大とともに 増加し, ケイ酸の除去が困難となることがわかる。原液 組成に示すごとく，No. 3〜No. 5 抽出液中のケイ酸量 は大差ないにもかかわらずソーダ配合量の少ない No. 3 抽出液では，いずれの添加剤でも残留ケイ酸は約 $32 \mathrm{mg} /$ $l, \mathrm{SiO}_{2} / \mathrm{Al}_{2} \mathrm{O}_{3} \times 100$ の值は約 0.07 で, ソーダ灰配合量 の多い No. 4 5 抽出液と比較して低い值を示し, 抽出 液中のアルカリ濃度が脱ケ个酸に相当影響があることが 十分考光られる。

\section{5. ドロマイトによる脱ケイ酸の機構}

高温加庄方式による脱ケイ酸処理実験の結果, ドロマ イト (生鉱; 焼鉱) を添加荗として用いた場合 $\mathrm{SiO}_{2} /$ $\mathrm{Al}_{2} \mathrm{O}_{3} \times 100$ の值が目標值の 0.03 亿近い良好な結果が得 られたので，その脱ケイ機構を明らかにするため脱ケイ

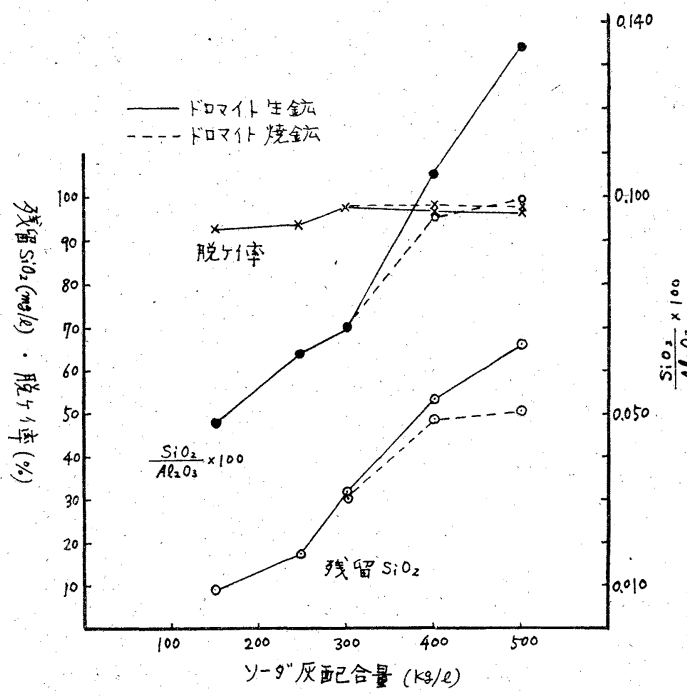

\begin{tabular}{|c|c|c|c|c|c|c|c|c|}
\hline \multicolumn{2}{|c|}{ 抽出原液の種類 } & \multicolumn{3}{|c|}{ 原 } & 液 & 組 & 成 & $\therefore$ \\
\hline No. & $\begin{array}{l}\text { ソーダ灰 } \\
\text { 配 合 量 }\end{array}$ & $\begin{array}{l}\mathrm{SiO}_{2} \\
(\mathrm{~g} / l)\end{array}$ & $\mid \begin{array}{l}\mathrm{Al}_{2} \mathrm{O}_{3} \\
(\mathrm{~g} / l)\end{array}$ & $\left|\begin{array}{c}\mathrm{CrO}_{3} \\
(\mathrm{~g} / l)\end{array}\right|$ & $\left|\begin{array}{r}\mathrm{NaOH} \\
(\mathrm{g} / l)\end{array}\right|$ & $\left|\begin{array}{c}\mathrm{Na}_{2} \\
\mathrm{CO}_{3} \\
(\mathrm{~g} / l)\end{array}\right|$ & $\left|\begin{array}{l}\mathrm{T} \\
\mathrm{Na}_{2} \mathrm{O} \\
(\mathrm{g} / l)\end{array}\right|$ & $\frac{\mathrm{SiO}_{2} \times 100}{\mathrm{Al}_{2} \mathrm{O}_{3}}$ \\
\hline $\begin{array}{l}1 \\
2 \\
3 \\
4 \\
5\end{array}$ & $\begin{array}{l}150 \mathrm{~kg} / \mathrm{t} \\
248 \mathrm{~kg} / \mathrm{t} \\
300 \mathrm{~kg} / \mathrm{t} \\
400 \mathrm{~kg} / \mathrm{t} \\
500 \mathrm{~kg} / \mathrm{t}\end{array}$ & $\begin{array}{l}0.120 \\
0.270 \\
1.525 \\
1.300 \\
1.830\end{array}$ & \begin{tabular}{|l|}
18.45 \\
29.30 \\
49.15 \\
55.00 \\
54.25
\end{tabular} & \begin{tabular}{|r|}
9.91 \\
21.38 \\
14.97 \\
17.60 \\
14.89
\end{tabular} & \begin{tabular}{|l|}
13.87 \\
26.88 \\
58.97 \\
83.49 \\
96.73
\end{tabular} & \begin{tabular}{|l|}
23.43 \\
36.87 \\
39.85 \\
41.51 \\
42.72 \\
\end{tabular} & \begin{tabular}{|l|}
24.45 \\
42.69 \\
69.02 \\
88.98 \\
99.99 \\
\end{tabular} & $\begin{array}{l}0.650 \\
0.922 \\
3.103 \\
2.364 \\
.3 .367\end{array}$ \\
\hline
\end{tabular}

第1図ソーダ配合量の脱ケイ率に执よぼす影響
酸処理を行なつた際の生成物を組成分析㧍よびX線回折 によつて検討した。すなおち抽出液に添加剤としてドロ マイト生鉱 $(-200 \mathrm{mesh})$ を $10 \mathrm{~g} / \mathrm{l}$ 加えてオートクレーブ を用いた高温加圧方式 $\left(170^{\circ} \mathrm{C}, 2 \mathrm{~h}\right)$ により脱ケイ酸処

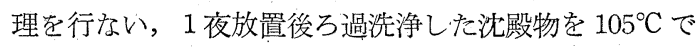
2 時間乾燥したものと添加剂に用いたドロマイト生鉱物 の組成分析結果を第 6 表に示す。

第6表 ドロマイト挔よび脱ケイ生成物分析表

\begin{tabular}{|c|c|c|c|c|c|c|c|c|}
\hline 試 & $\begin{array}{l}\mathrm{H}_{2} \mathrm{O} \\
(\%)\end{array}$ & \begin{tabular}{|l|}
$\begin{array}{l}\mathrm{SiO}_{2} \\
(\%)\end{array}$ \\
\end{tabular} & $\left|\begin{array}{c}\mathrm{Al}_{2} \mathrm{O}_{3} \\
(\%)\end{array}\right|$ & $\begin{array}{l}\mathrm{CaO} \\
(\%)\end{array}$ & $\left|\begin{array}{c|}\mathrm{MgO} \\
(\%)\end{array}\right|$ & $\left|\begin{array}{c}\mathrm{Cr}_{2} \mathrm{O}_{3} \\
(\%)\end{array}\right|$ & \begin{tabular}{|l|}
$\mathrm{CO}_{2}$ \\
$(\%)$
\end{tabular} & $\begin{array}{l}\mathrm{Na}_{2} \mathrm{O} \\
(\%)\end{array}$ \\
\hline ロマイト & & 0.45 & 1.37 & 35.09 & 17.46 & $6 \quad-*$ & & $-^{*}$ \\
\hline 说ケイ生成物 & 4.95 & 5.67 & 20.09 & 29.29 & 15.77 & 0.35 & $|27.23|$ & 1.51 \\
\hline
\end{tabular}

(*印成分は分析を行なっていない)

これからわかるよらに生成物中の主成分はドロマイト であるが，その他に $\mathrm{Al}_{2} \mathrm{O}_{3}, \mathrm{SiO}_{2}$ がかなり多量に含ま れている。 $\mathrm{Na}_{2} \mathrm{O}$ は $1.5 \%$ 程度でこれは生成物中に Sodalite族化合物が混在するものと考えられ，Cr注含有量も 低いことから洗浄不十分による吸着と考えられる。

次にドロマイト生鉱および焼鉱ならびにこれらドロマ イトにミルスケールを添加混合したものなどを用いた場 合の脱ケイ酸生成物をX線回折によつてその構造を調べ た結果を第 2 図に示す。(A)生鉱ドロマイトを用いた場 合の生成物の回折線図で, これを ASTM カードで比較 検討した結果，添加した $\mathrm{MgCa}\left(\mathrm{CO}_{3}\right)_{2}$ および $\mathrm{CaCO}_{3}$ の回折線の他に Calcium silicate hydrate, Calcium aluminum hydroxideの強い回折線を確認した。その他 に Basic calcium magnesium silicate hydrate, Basic aluminum silicate, Calcium aluminum hydrate $5 し$ き回折線もあるが確認は困難であつた。Bはドロマイト 焼鉱を用いた場合の生成物の回折線図で, $\mathrm{Mg}(\mathrm{OH})_{2}$ 以外 はすべて(A)と同様の回折線を示した。またドロマイト生

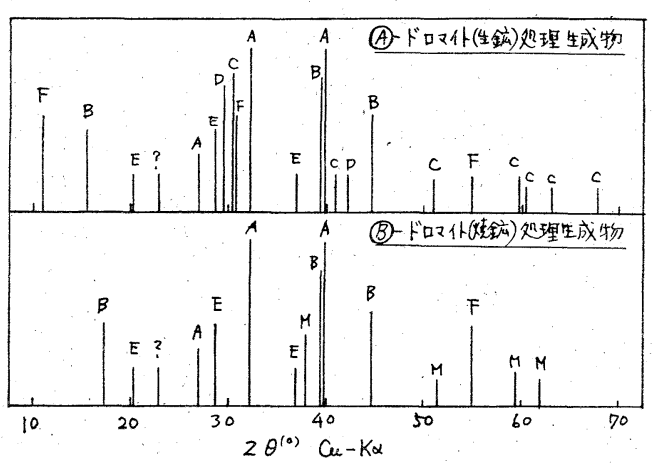


鉱にミルスケールを $10 \%$ 混合したものと,これを $1,000^{\circ} \mathrm{C}$ で 2 時間力焼して用いた場合の生成物の回折線は, 前者 は(A)と，後者は(B)と全く同一の回折線を示し，添加した ミルスケールすなわち鉄系化合物の回折線は確認が困難 であつた。これら脱ケイ生成物中の Calcium. silicate hydrate は数多くの異なつた回折線がある中の $\mathrm{Ca}_{2} \mathrm{SiO}_{4}$

・1 $1 / 2 \mathrm{H}_{2} \mathrm{O}$ であることも確認しだ。

\section{$5 \cdot 1$ 生成物の焼成による变化}

ドロマイト（生鉱）を用いた場合の脱ケイ生成物につ いて，示差熱分析を行ない，その熱変化を検討した ${ }^{6}$ 。 すなわち, 試料 $0.5 \mathrm{~g}$ を秤取し, 炉の温度上昇速度を 10 ${ }^{\circ} \mathrm{C} / \mathrm{min}$ とし, 熱変化曲線を求めた結果を第 3 図- $\mathrm{A}$ に 示す。これによると, $250^{\circ} \mathrm{C}$ 付近にやや鋭い吸熱ピーク と $410^{\circ} \mathrm{C}$ 付近に弱い吸熱のピーク,さらに $440^{\circ} \mathrm{C}$ $540^{\circ} \mathrm{C}$ 付近にやや鋭い吸熱のピークが現われている。これは 250 ${ }^{\circ} \mathrm{C}$ に挍いて結晶水の脱水, $410^{\circ} \mathrm{C}$ では $\mathrm{Mg}(\mathrm{OH})_{2}$ の分解, $540^{\circ} \mathrm{C}$ では $\mathrm{Ca}(\mathrm{OH})_{2}$ の分解を示すものと考光られ $440^{\circ} \mathrm{C}$ の吸熱ピークは生成した化合物, すなわち Calcium silicate hydrate, Calcium aluminum hydroxide など の分解が考えられる。また $780^{\circ} \mathrm{C}$ 付近と $860^{\circ} \mathrm{C}$ 付近の鋭い 吸熱のピークは添加したドロマイトの分解によるもので ある。これからわかるように，ドロマイト以外の化合物 のすべてが, $550^{\circ} \mathrm{C}$ 以下で完全に変化しているとがわか つたので, 上述の生成物を $550^{\circ} \mathrm{C}$ で 1 時間力焼後の試料 についてX線回折によつてその構造を検討した結果を第 3 図-Bに示す。

これによると主成分のドロマイトの回折線の外に, Calcium silicate, Calcium aluminum oxide の回折線 が強く確認され，またドロマイトの回折線と一部重なる

\section{A 示差槃曲線}

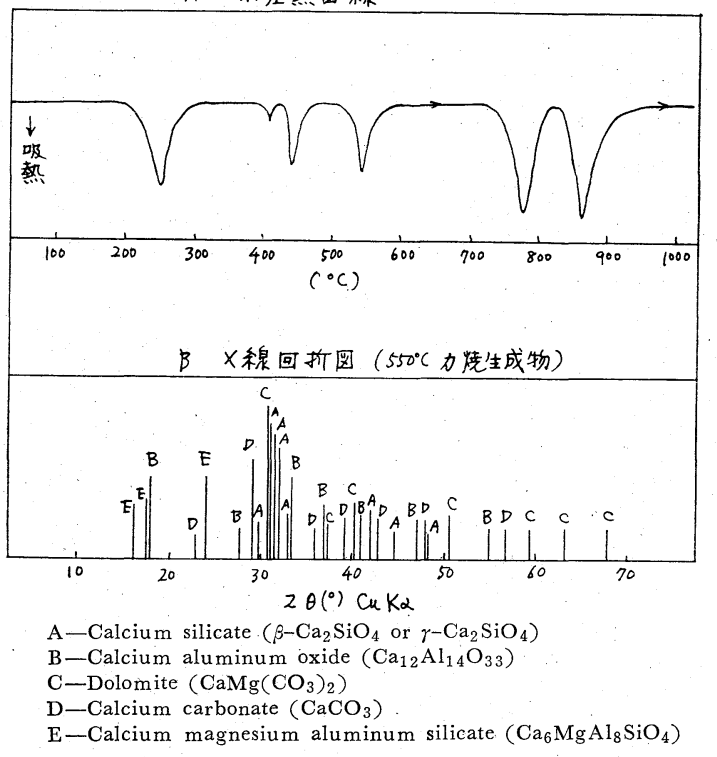

第3図脱ヶイ生成物の焼成による変化
が Calcium magnesium aluminum silicate の回折線 も弱いが確認された。確認された Calcium silicate は $\beta-\mathrm{Ca}_{2} \mathrm{SiO}_{4}$ と $\gamma-\mathrm{Ca}_{2} \mathrm{SiO}_{4}$ で, Calcium aluminum oxide $\mathrm{Ca}_{12} \mathrm{Al}_{14} \mathrm{O}_{33}$ であることもわかつた。以上X線回 折の結果からドロマイトを脱ケイ阂として用いた場合の 脱ケイ生成物の形態が Calcium silicate hydrate およ び Calcium aluminum hydroxide が主体であることが 燒成物からも認められ，確認されたカルシウムシリケー 卜水和物は, $\mathrm{CaO}-\mathrm{SiO}_{2}-\mathrm{H}_{2} \mathrm{O} 3$ 成分系偶属する多くの 化合物中の Rustumite の組成と一致する。な预組成分 析の結果から $\mathrm{Na}_{2} \mathrm{O}$ がわずかに含有されているので, Sodalite 族化合物の混在も十分考光られるが X 線回折 図よりの確認は困難であつた。

\section{6. 結言}

ソーダ焙燒抽出液の脱ケイ酸を目的とし, 精製液のケ イ酸濃度を目標值まで下げる処理方法につき脱ケイ斉门 選択, 处理条件などの基礎的研究を行ない, 高純度アル ミナ製造に必要なケイ酸濃度すなわち $\mathrm{SiO}_{2} / \mathrm{Al}_{2} \mathrm{O}_{3} \times 100$ $=0.03$ 目標值に達する方法を確立することができた。

最適条件としては，脱ケイ凨としてドロマイト（生鉱 の場合は，-200mesh，焼鉱ではー100mesh）を10 20 $\mathrm{g} / \mathrm{l}$ 添加してオートクレーブを用いて $170^{\circ} \mathrm{C} て ゙ ~ 2$ 時間高 温加圧処理を行ない，1夜放置後ろ過洗浄して精製液と する。なおドロマイトにミルスケールを添加混合すると さらに好結果が得られ， $\mathrm{Al}_{2} \mathrm{O}_{3}$ の損失も10\%前後におさ えることができる。脱ケイ鼡としてのドロマイトの粒度 は，生鉱では粉研度がかなり影響しー200meshを必要と し，焼鉱の場合は一100mesh程度の粉砕度で一定した結 果が得られる。またドロマイトはケイ酸の少ない純度の よいものがのぞましい。

ドロマイトを用いた場合の脱ケイ生成物は Calcium silicate hydrate, Calcium aluminum hydroxide が主 体で, その他に Basic calcium magnesium silicate hydrate, Basic aluminum silicate, Calcium aluminum hydrateと近似の回折線が現われているが, Sodalite 族の回折線の確認は困難であつた。

またカルシウム系添加剤も $\mathrm{SiO}_{2} / \mathrm{Al}_{2} \mathrm{O}_{3} \times 100$ の值が $0.5 \sim 0.6$ に低下し, 添加量の増加とともに脱ケイ率も 98 $\%$ と上昇しているが，精製液の $\mathrm{Al}_{2} \mathrm{O}_{3}$ の減少がはなは だしく $20 \%$ 以上の損失率を示した。

\section{参考文 献}

1) Edited by G. Gerard \& p. T. Stroup: Extractive Metallurgy of Aluminum. Vol. 1, Alumina

2）日本金属学会：非鉄金属製錬(昭 39) p. 260

3) 須藤俊男 : 鉣物化学II (昭34) p. $244 \sim 248$

4）森・清宮・石川：軽金属, No. 24 (1957) 32

5）エ・イ・ベリヤエフ：軽金属治金学，p. 43

6) 清宮・森: 軽金属, Vol. 12, No. 55 (1962) 6 